Article

\title{
Investigating the Antioxidant and Cytocompatibility of Mimusops elengi Linn Extract over Human Gingival Fibroblast Cells
}

\author{
Shaeesta Khaleelahmed Bhavikatti $\left.{ }^{1,2, *,+}{ }^{(}\right)$, Mohmed Isaqali Karobari ${ }^{3,4,+}$ (D), Siti Lailatul Akmar Zainuddin ${ }^{1}$, \\ Anand Marya ${ }^{5,6}{ }^{(D}$, Sameer J. Nadaf ${ }^{7}{ }^{10}$, Vijay J. Sawant ${ }^{8}{ }^{(D}$, Sandeep B. Patil ${ }^{9}$, Adith Venugopal ${ }^{6}$, \\ Pietro Messina ${ }^{10}$ and Giuseppe Alessandro Scardina ${ }^{10, *(D)}$
}

Citation: Bhavikatti, S.K.; Karobari, M.I.; Zainuddin, S.L.A.; Marya, A.; Nadaf, S.J.; Sawant, V.J.; Patil, S.B.; Venugopal, A.; Messina, P.; Scardina, G.A. Investigating the Antioxidant and Cytocompatibility of Mimusops elengi Linn Extract over Human Gingival Fibroblast Cells. Int. J. Environ. Res. Public Health 2021, 18, 7162. https://doi.org/10.3390/ ijerph18137162

Academic Editor: Chethan Sampath

Received: 26 May 2021

Accepted: 29 June 2021

Published: 4 July 2021

Publisher's Note: MDPI stays neutral with regard to jurisdictional claims in published maps and institutional affiliations.

Copyright: (c) 2021 by the authors. Licensee MDPI, Basel, Switzerland. This article is an open access article distributed under the terms and conditions of the Creative Commons Attribution (CC BY) license (https:/ / creativecommons.org/licenses/by/ $4.0 /)$.
1 Department of Periodontics, School of Dental Sciences, Universiti Sains Malaysia, Health Campus, Kubang Kerian 16150, Malaysia; lailatul@usm.my or sitilaz@usm.my

2 Division of Periodontics and Community Dental Sciences, College of Dentistry, King Khalid University, Abha 62529, Saudi Arabia

3 Conservative Dentistry Unit, School of Dental Sciences, Universiti Sains Malaysia, Health Campus, Kubang Kerian 16150, Malaysia; dr.isaq@gmail.com

4 Department of Conservative Dentistry \& Endodontics, Saveetha Dental College \& Hospitals, Saveetha Institute of Medical and Technical Sciences University, Chennai 600077, India

5 Department of Orthodontics, Faculty of Dentistry University of Puthisastra, Phnom Penh 12211, Cambodia; amarya@puthisastra.edu.kh

6 Department of Orthodontics, Saveetha Institute of Medical and Technical Sciences, Saveetha Dental College, Saveetha University, Chennai 600077, India; avenugopal@puthisastra.edu.kh

7 Sant Gajanan Maharaj College of Pharmacy, Mahagaon 416503, India; sam.nadaf@rediffmail.com

8 Department of Chemistry, Smt. K. W. College, Sangli 416416, India; sawantvjkwc@gmail.com

9 Department of Pharmacology, Dr. Shivajirao Kadam College of Pharmacy, Kasbe digraj, Sangli 416305, India; sandeeppharmacology@gmail.com

10 Department of Surgical Oncological and Stomatological Disciplines, University of Palermo, 90133 Palermo, Italy; pietro.messina01@unipa.it

* Correspondence: drshaeesta@gmail.com (S.K.B.); alessandro.scardina@unipa.it (G.A.S.)

+ Both the authors contributed equally.

Abstract: Background-chlorhexidine (CHX) is most commonly used as a chemical plaque control agent. Nevertheless, its adverse effects, including teeth discoloration, taste alteration and calculus build-up, limit its use and divert us to medicinal herbs. The purpose of the study was to evaluate the phytochemical composition, antioxidant potential, and cytotoxic effects of Mimusops elengi Linn extract (ME) over normal human cultured adult gingival fibroblasts (HGFs). Methods-in vitro phytochemical screening, total flavonoid content, antioxidant potential by DPPH and Nitric Oxide (NO) radical scavenging activity, and cytotoxic effects of ME extracts over HGF were explored. The viability of HGF cells was determined using 3-(4,5-dimethylthiazol-2-yl)-2, 5-diphenyl tetrazolium bromide (MTT), neutral red uptake, and trypan blue assay after treatment with different concentrations of CHX and ME (0.3125 to $10 \mu \mathrm{g} / \mathrm{mL})$. Results-ME showed some alkaloids, glycosides, saponins and flavonoids exhibited relatively moderate-to-good antioxidant potential. Increasing the concentration of $\mathrm{CHX}$ and ME from 0.3125 to $10 \mu \mathrm{g} / \mathrm{mL}$ reduced cell viability from $29.71 \%$ to $1.07 \%$ and $96.12 \%$ to $56.02 \%$, respectively. At higher concentrations, $\mathrm{CHX}$ reduced the viability of cells by 52.36 -fold compared to ME, revealed by MTT assay. At $10 \mu \mathrm{g} / \mathrm{mL}$ concentration, the mean cell viability of CHX and ME-treated cells was $2.24 \%$ and $57.45 \%$, respectively, revealed by a neutral red assay. The viability of CHX- and ME-treated HGF cells estimated at higher concentrations $(10 \mu \mathrm{g} / \mathrm{mL})$ using trypan blue assay was found to be $2.18 \%$ and $47.36 \%$, respectively. A paired $t$-test showed significance $(p<0.05)$, and one-way ANOVA difference between the mean cell viability of $\mathrm{CHX}$ - and ME-treated cells at different concentrations. One-way ANOVA confirmed the significant difference between the viability of CHX- and ME-treated cells. Conclusions-The cytoprotective and antioxidant effects of ME emphasize its potential benefits. Therefore, it could emerge as a herbal alternative and adjunct to conventional oral hygiene methods, that can diminish periodontal tissue destruction. 
Keywords: chlorhexidine; cytotoxicity; fibroblast; gingival; herbs; medicinal

\section{Introduction}

A dental plaque is a structurally and functionally organized biofilm of diverse microbial composition [1]. Accumulation of dental plaque is ultimately known to result in caries, gingivitis, and periodontal diseases [2]. Periodontitis is a common oral inflammatory disease, multifactorial in its etiology and associated with the destruction of the periodontium and the tissues supporting the tooth. The primary cause for such periodontal destruction is oral bacteria that eventually result in tooth loss [3]. There is a plethora of evidence implicating reactive oxygen species (ROS), derived predominantly from polymorphonuclear leukocytes, in the pathogenesis of periodontal tissue destruction. These ROS cause tissue damage through an array of different mechanisms, such as DNA damage, lipid peroxidation, protein disruption and stimulation of inflammatory cytokine release [4-6]. Therefore, combating this oxidative stress using safe, economic medications and having the least or no adverse effects could possibly assist periodontal disease management.

Chemical plaque control measures are used as adjuvants to conventional mechanical methods and are known to interfere with biofilm composition and metabolism [3]. Among the mouthwashes used for chemical plaque control, chlorhexidine gluconate (CHX) is the most used antiplaque agent and is considered the "gold standard" owing to its broadspectrum antimicrobial activity against different oral pathogens such as Streptococcus mutans, Streptococcus oralis, Lactobacillus acidophilus, Lactobacillus fermentum, Candida albicans, etc. $[7,8]$. However, specific side effects like tooth staining, taste disturbance, calculus buildup, etc., have limited its applications [7,9]. Very recently, a study by Polizzi et al. (2019) revealed that $\mathrm{CHX} 0.12 \%$ with alcohol and $\mathrm{CHX} 0.20 \%$ with alcohol mouthwashes showed a significant presence of extrinsic tooth staining [10]. The human gingival fibroblasts (HGFs) are essential periodontal connective tissue cells that aid in wound healing. Cytotoxic effects of the chemical plaque control agents over the HGFs are a matter of concern. There is documented evidence of the cytotoxic effects of CHX over the HGFs. Coelho et al. (2020) observed that exposure of the fibroblasts to the mouthwashes caused a G2/M phase block and cell death predominantly by necrosis [11]. This directs towards the use of chemical plaque control agents with cytoprotective effects.

Several natural plant-based products are widely used for diverse therapeutic applications owing to their safe and potential medicinal properties $[12,13]$. Recently available studies offer essential data that herbal products may comprise akin antimicrobial potential to reputable chemotherapeutics. The World Health Organization guidelines define herbal medicines as finished, labeled medicinal products containing an active ingredient, i.e., obtained from the aerial or underground parts of botanicals or other plant materials or their combination [14]. Specifically, since ancient days, Mimusops elengi Lin, a wild plant distributed in tropical and subtropical regions belonging to the family Sapotaceae, has been known for its myriad of medicinal values [15]. So far, various parts of the plant have been used in traditional medicine to manage pain, inflammation, wounds and so on [16]. It has several known benefits such as anti-bacterial, antiviral, anti-inflammatory, antihyperglycemic, antioxidant, etc. [17]. Chewing of the root bark strengthens the teeth and escalates oral health [18]. In Ayurveda, M. elengi has been reported to be used for arresting bleeding gums [19]. The use of unripe fruit and seed for fixing loose teeth is documented [20]. Herbal mouth rinse derived from M. elengi bark aqueous extract acts as a potent plaque inhibitor and anti-inflammatory agent in gingivitis [21]. Chloroform extract of M. elengi bark exhibited prominent anti-bacterial activity in dental patients by the ditch plate technique [22]. Whereas, ethanolic extracts of bark, leaves and seeds M. elengi are reported to be anti-bacterial agents against some pathogens [23].

Notably, for administrating agents, along with the antimicrobial activity against the oral pathogens, selective cytotoxicity towards bacteria with diminished toxic effects to host 
cells is also equally essential [24-26]. Though studies are reporting the beneficial properties of this herb against oral pathogens, there is a paucity of literature on its cytocompatibility. In comparison with previous reports, our study investigated cytocompatibility of M. elengi extract against HGF cells and related it with CHX using three different cytotoxicity assays. Further, the present investigation included potential antioxidant determination of the aforementioned extract, which gives insights into the mechanism. Collectively, this leads to the hypothesis that ME may have lesser toxic effects on HGF cells than CHX.

Hence, the primary objectives of this study were to screen the phytochemical composition, antioxidant capacities and determine and compare the cytocompatibility activity of ME with CHX (available as Rexidin $0.2 \%$ ) over HGFs.

\section{Materials and Methods}

\subsection{Study Protocol}

An in vitro experimental design was adopted to perform the study. The study was registered in the Scientific Research Committee, College of Dentistry, King Khalid University (SRC/REG/2018-2019/91). The study was conducted in full accordance with the declared ethical principles (World Medical Association Declaration of Helsinki, version VII, 2013. Ethical clearance was obtained from the institution's independent ethics committee (Approval No. SRC/ETH/2018-19/116).

\subsection{Collection of Plant Material and Processing of the Extract}

The bark of Mimusops elengi Linn was collected from the surrounding regions of Maharashtra, India. The plant material was identified and authenticated by a botanist. A voucher specimen of each plant was deposited in the department. Plant materials were washed with tap water and dried in an oven at $45^{\circ} \mathrm{C}$ for seven days. The material was ground; the fine powder was made and stored in an air-tight container until use. The coarse powder was packed in a Soxhlet apparatus and continuously extracted with petroleum ether at temperature $100-120^{\circ} \mathrm{C}$ till all fat constituents were separated out and then extracted with ethanol at temperature $60-80^{\circ} \mathrm{C}$ till all the constituents were separated. For a powder weight of $100 \mathrm{gms}$, the extractive value was $13 \%$.

\subsection{Phytochemical Screening}

Qualitative phytochemical screening was performed to check the presence of alkaloids, sterols, glycosides, flavonoids, tannins, proteins, as per standard protocol (Table 1).

\subsection{Evaluation of Total Flavanoid Content}

The aluminum chloride colorimetric assay measured total flavonoid content. Briefly, the reaction mixture containing $1 \mathrm{~mL}$ of ethanolic extract and $4 \mathrm{~mL}$ of distilled water was prepared in a $10 \mathrm{~mL}$ volumetric flask and to which $0.30 \mathrm{~mL}$ of $5 \%$ sodium nitrite was added. After $5 \mathrm{~min}, 0.3 \mathrm{~mL}$ of $10 \%$ aluminum chloride was added and mixed. Then, $2 \mathrm{~mL}$ of $1 \mathrm{M}$ sodium hydroxide was treated and diluted to $10 \mathrm{~mL}$ with distilled water. A similar set of reference standard solutions of quercetin $(200,400,600,800$ and $1000 \mu \mathrm{g} / \mathrm{mL})$ was prepared. The absorbance for test and standard solutions was determined against the reagent blank at $510 \mathrm{~nm}$ using a spectrophotometer. The total flavonoid content was expressed as $\mathrm{mg}$ of quercetin equivalents (QE) per $\mathrm{g}$ of extract. The absorbance of the test sample was performed in triplicate (Figure 1). 
Table 1. Active ingredients in the ME as evaluated.

\begin{tabular}{|c|c|c|c|}
\hline Chemical Constituents & Name of Test & Observed Changes & Result \\
\hline \multirow{4}{*}{ Alkaloids } & Mayer's Reagent & White-colored turbidity & + \\
\hline & Wagner's Reagent & Reddish Brown Precipitate & + \\
\hline & Hager's Reagent & Yellow Precipitate floating & + \\
\hline & Ehrlich's Reagent & Two separate yellow and brown colored layers & + \\
\hline \multirow{2}{*}{ Sterols \&Triterpenoids } & Salkowaski test & The lower layer turns red & + \\
\hline & Sulphur test & Sinks in it & + \\
\hline \multirow{3}{*}{ Glycosides } & Baljet's test & Yellow to orange color. & + \\
\hline & & No Separation between two layers, lower layer & \\
\hline & Keller killani test & $\begin{array}{c}\text { reddish-brown and upper layer turns } \\
\text { bluish-green }\end{array}$ & + \\
\hline \multirow{2}{*}{$\begin{array}{l}\text { Anthraquinone glycosides } \\
\text { Saponins }\end{array}$} & Borntrager's test & The ammonical layer turns pink or red. & + \\
\hline & Foam test & Formation of foam & + \\
\hline \multirow{3}{*}{ Carbohydrates } & Molisch's test: & & ND \\
\hline & Barfoed's test & & ND \\
\hline & Benedict's test & Reddish-brown precipitate & + \\
\hline \multirow{3}{*}{ Flavonoids } & Shinoda test & Pink to magenta-red color & + \\
\hline & Alkaline reagent test & Yellow color becomes a color lesson & + \\
\hline & Lead acetate solution test & Yellow precipitate & + \\
\hline Tannins & Ferric-chloride test & Dark color & + \\
\hline \multirow{4}{*}{ Proteins } & Millon's test & & ND \\
\hline & Xanthoproteic test & No Yellow precipitate & - \\
\hline & Biuret test & No Blue color & - \\
\hline & Ninhydrin test & No Blue color. & - \\
\hline
\end{tabular}

Note: + , indicates the presence of phytoconstituents; ${ }_{-}$, indicates an absence of phytoconstituents; ND, indicates not determined.

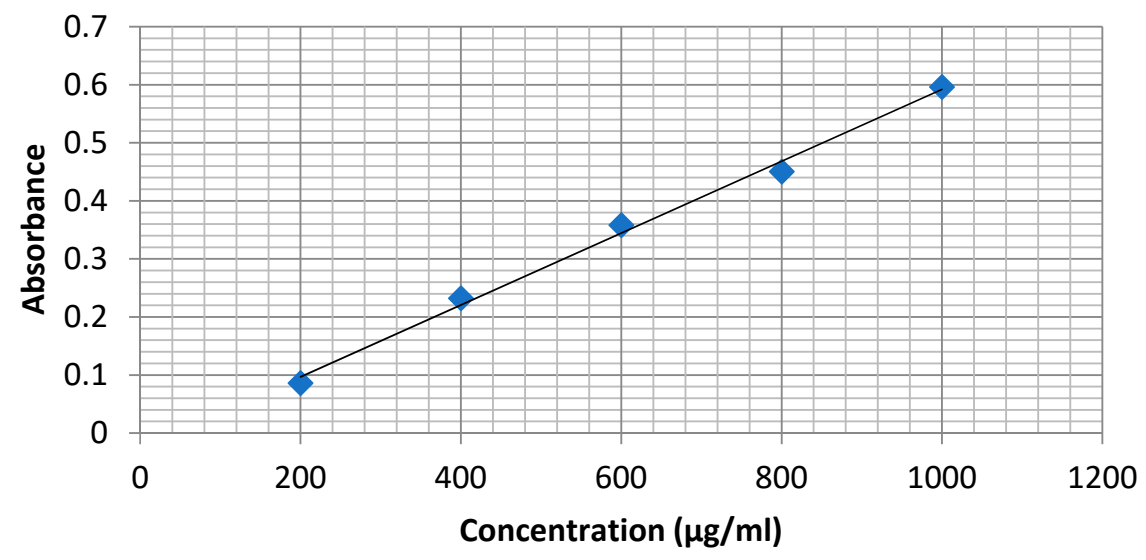

Figure 1. Calibration curve of Quercetin.

\subsection{Quantification of Antioxidant Activities}

\subsubsection{DPPH Free Radical Scavenging Assay}

Molecule 1, 1-diphenyl-2-picrylhydrazyl (a a-diphenyl-bpicrylhydrazyl; DPPH) is characterized as a stable free radical by virtue of the delocalization of the spare electron over the molecule as a whole so that the molecule does not dimerize, as would be the case with most other free radicals. The delocalization of electrons also gives rise to the deep violet color, characterized by an absorption band in ethanol solution centered at about $517 \mathrm{~nm}$. When a solution of DPPH is mixed with that of a substrate (AH) that can donate a hydrogen atom, this gives rise to the reduced form with the loss of this violet color.

The ability of compounds to scavenge the DPPH radical was assessed using the previously reported method $[27,28]$ with few modifications. Briefly, $1 \mathrm{~mL}$ of herbal extract 
(200, 400, 600, 800, and $1000 \mu \mathrm{g} / \mathrm{mL})$ was mixed with $3.0 \mathrm{~mL}$ DPPH $(0.5 \mathrm{mmol} / \mathrm{L}$ in methanol), and the resultant absorbance was recorded at $517 \mathrm{~nm}$ after $30 \mathrm{~min}$ incubation at $37^{\circ} \mathrm{C}$. The percentage of scavenging activity was derived using the following formula,

$$
\text { Percentage of inhibition }(\%)=\left(\frac{\text { A control }- \text { A sample }}{\text { A control }}\right) \times 100
$$

where A control—absorbance of DPPH, A sample—absorbance reaction mixture (DPPH with Sample).

\subsubsection{Nitric Oxide Radical Scavenging Activity}

NO. is generated in biological tissues by specific nitric oxide synthases, which metabolize arginine to citrulline with the formation of NO. via a five-electron oxidative reaction [29]. The compound sodium nitroprusside is known to decompose in an aqueous solution at physiological $\mathrm{pH}$ (7.2), producing NO. Under aerobic conditions, NO. reacts with oxygen to produce stable products (nitrate and nitrite), the quantities of which can be determined using Griess reagent [30].

A total of $1 \mathrm{~mL}$ of $10 \mathrm{mM}$ sodium nitroprusside dissolved in $0.5 \mathrm{~mL}$ phosphate buffer saline ( $\mathrm{pH}$ 7.4) was mixed with $1 \mathrm{~mL}$ of $1 \mathrm{mM}$ synthetic compounds in DMSO. The mixture was incubated at $25{ }^{\circ} \mathrm{C}$ for $150 \mathrm{~min}$. After incubation, the reaction mixture was mixed with $1.0 \mathrm{~mL}$ of pre-prepared Griess reagent $(1.0 \mathrm{~mL}$ sulfanilic acid reagent $(0.33 \%$ in $20 \%$ glacial acetic acid at room temperature for 5 min with $1 \mathrm{~mL}$ of naphthylethylenediamine dichloride $(0.1 \% w / v))$. The mixture was then incubated at room temperature for $30 \mathrm{~min}$ and its absorbance poured into a cuvette was measured at $546 \mathrm{~nm}$. The decreasing absorbance indicates a high nitric oxide scavenging activity.

The amount of nitric oxide radical inhibition was calculated following this equation:

$$
\% \text { inhibition of NO radical }=\left(\frac{\mathrm{A}_{0}-\mathrm{A}_{1}}{\mathrm{~A}_{0}}\right) \times 100
$$

where $\mathrm{A}_{0}$ is the absorbance before reaction and $\mathrm{A}_{1}$ is the absorbance after the reaction has taken place with the Griess reagent.

\subsection{Cytotoxic Activity}

\subsubsection{Materials}

Dulbecco's Modified Eagle Media (DMEM) and Fetal bovine serum (FBS) with low glucose were purchased from Gibco, Invitrogen. Antimycotic $100 \times$ solution was procured from Thermofisher Scientific. Neutral Red GRM122 and Trypan blue TC193 were procured from Hi-Media, Mumbai.

\subsubsection{Cell Culture}

After obtaining informed consent, normal human adult primary gingival fibroblast (HGF) cells were obtained from healthy gingival tissue of a human adult premolar that was excised during periodontal surgery. These cells were cultured in Dulbecco's Modified Eagle Media (DMEM medium). Further, it was supplemented with 10\% fetal calf serum (FBS) and $1 \%$ Antibiotic-Antimycotic $100 \times$ solution followed by incubation in $\mathrm{CO}_{2}$ incubator (Eppendorf, New Brunswick, Galaxy $170 \mathrm{R}$, Germany) maintained at $37^{\circ} \mathrm{C}, 5 \% \mathrm{CO}_{2}$ with $95 \%$ humidity until the completion of experiments [31].

\subsubsection{MTT Assay}

The cells were seeded in a 96-well flat-bottom microplate and maintained at $37{ }^{\circ} \mathrm{C}$ in $95 \%$ humidity and $5 \% \mathrm{CO}_{2}$ overnight. Different concentrations $(10 \%, 5 \%, 2.5 \%, 1.25 \%$, $0.625 \%, 0.312 \% w / v)$ of samples were treated. The cells were incubated for another $48 \mathrm{~h}$. The wells were washed twice with Phosphate Buffered Saline (PBS), and $20 \mu \mathrm{L}$ of the MTT staining solution was added to each well, and the plate was incubated at $37^{\circ} \mathrm{C}$. 
After $4 \mathrm{~h}, 100 \mu \mathrm{L}$ of dimethyl sulfoxide (DMSO) was added to each well to dissolve the formazan crystals, and optical density (OD) was recorded with a $570 \mathrm{~nm}$ using a microplate reader [32].

Formula:

$$
\text { Surviving cells }(\%)=\left(\frac{\text { Mean OD of test compound }}{\text { Mean OD of Negative control }}\right) \times 100
$$

\subsubsection{Neutral Red Uptake Assay}

Approximately $5 \times 10^{4}$ cells per well were plated in 96-well plates, and DMEM containing $5 \%$ FBS was added and allowed to attach overnight. Different concentrations $(10 \%, 5 \%, 2.5 \%, 1.25 \%, 0.625 \%, 0.312 \% w / v)$ of samples were treated. The cells were incubated for another $48 \mathrm{~h}$. The wells were washed twice with PBS. A total of $100 \mathrm{~mL}$ of neutral red medium was added to each well of the plate. The plate was incubated for $2 \mathrm{~h}$ at the appropriate culture conditions. The neutral red medium was removed, and the wells were washed with PBS. A total of $150 \mathrm{~mL}$ neutral red de-stain solution was then added per well. The plate was shaken rapidly on a microtiter plate shaker for at least $10 \mathrm{~min}$, or until the neutral red had been extracted from the cells and had formed a homogeneous solution. The OD of the neutral red extract was measured at $540 \mathrm{~nm}$ in a microtiter plate reader spectrophotometer, using blanks that contain no cells as a reference [33].

\subsubsection{Trypan Blue Assay}

Approximately $5 \times 10^{4}$ cells per well were plated in 96-well plates, and DMEM containing 5\% FBS was added and allowed to attach overnight. Different concentrations $(10 \%$, $5 \%, 2.5 \%, 1.25 \%, 0.625 \%, 0.312 \% v / v)$ of samples were treated. The cells were incubated for another $48 \mathrm{~h}$. The wells were washed twice with PBS. The cell suspension was centrifuged for about $1500 \mathrm{rpm}$ for $3 \mathrm{~min}$, and the supernatant was discarded. The cell pellets were re-suspended in $1 \mathrm{~mL}$ PBS or serum-free complete medium. The $0.4 \%$ trypan blue and cell suspension were mixed. The mixture was incubated for $3 \mathrm{~min}$ at room temperature. A drop of the Trypan blue/cell mixture was applied to a hemacytometer. The hemacytometer was placed on the stage of a binocular microscope, and the focus was on the cells. The unstained (viable) and stained (nonviable) cells were counted separately in the hemacytometer. To obtain the total number of viable cells per ml of aliquot, the total number of viable cells was multiplied by the dilution factor for trypan blue. To obtain the total number of cells per $\mathrm{ml}$ of aliquot, the total number of viable and nonviable cells was added [34]. The percentage of viable cells was calculated as follows:

$$
\text { Viable cells }(\%)=\frac{\text { Total number of viable cells }}{\text { total number of cells }} \times 100
$$

\subsection{Statistical Analysis}

The normality of data was estimated using the Kolmogorov-Smirnov test and the Shapiro-Wilk test. Statistical difference was tested using one-way analysis of variance (ANOVA) followed by post-hoc Tukey HSD Test, Scheffé, Bonferroni and Holm multiple comparisons. To ensure the reliability of ME-treated HGF cell viability estimated using MTT, neutral red and Trypan blue assay, data were compared with each other using ANOVA. The same analysis was performed on the results of CHX-treated HGF cell viability. 


\section{Results}

\subsection{Phytochemical Analysis}

The results after phytochemical analysis are as depicted in Table 1.

\subsection{Total Flavanoid Content}

Total flavonoid contents were observed to be $867.52 \pm 6.53$ ( $\mu \mathrm{g} \mathrm{QE} / \mathrm{g}$ ). The calibration curve of quercetin is shown in Figure 1.

\subsection{Antioxidant Activities}

ME showed a concentration-dependent antioxidant effect against free radicals generated, revealed by DPPH and NO free radical scavenging assay. ME exhibited good activity compared with the standard drug when tested using DPPH assay, whereas it demonstrated moderate activity after testing using the NO radical scavenging assay. Detailed results are shown in Table 2.

Table 2. Antioxidant activities of Mimusops elengi Linn extract (DPPH and NO assays).

\begin{tabular}{|c|c|c|}
\hline \multicolumn{3}{|l|}{ DPPH ASSAY } \\
\hline Sample & Absorbance at $517 \mathrm{~nm}$ & $\%$ inhibition \\
\hline Control & 0.34 & \\
\hline Standard Ascorbic acid (1 mg/mL) & 0.04 & 88.23 \\
\hline $200 \mu \mathrm{g} / \mathrm{mL}$ & 0.14 & 58.82 \\
\hline $400 \mu \mathrm{g} / \mathrm{mL}$ & 0.10 & 70.58 \\
\hline $600 \mu \mathrm{g} / \mathrm{mL}$ & 0.08 & 76.47 \\
\hline $800 \mu \mathrm{g} / \mathrm{mL}$ & 0.07 & 79.41 \\
\hline $1000 \mu \mathrm{g} / \mathrm{mL}$ & 0.05 & 85.29 \\
\hline \multicolumn{3}{|l|}{ NO ASSAY } \\
\hline Sample & Absorbance at $546 \mathrm{~nm}$ & $\%$ inhibition \\
\hline Control & 1.64 & \\
\hline Standard Ascorbic acid (1 mg/mL) & 0.28 & 82.92 \\
\hline $200 \mu \mathrm{g} / \mathrm{mL}$ & 1.49 & 08.87 \\
\hline $400 \mu \mathrm{g} / \mathrm{mL}$ & 1.25 & 23.78 \\
\hline $600 \mu \mathrm{g} / \mathrm{mL}$ & 1.00 & 39.02 \\
\hline $800 \mu \mathrm{g} / \mathrm{mL}$ & 0.77 & 53.04 \\
\hline $1000 \mu \mathrm{g} / \mathrm{mL}$ & 0.74 & 54.87 \\
\hline
\end{tabular}

\subsection{Cytotoxicity Assay's}

\subsubsection{MTT Assay}

Both CHX and ME inhibited the proliferation of HGF cells but to a different extent in a dose-dependent matter. Increasing the concentration of $\mathrm{CHX}$ and $\mathrm{ME}$ from 0.3125 to $10 \mu \mathrm{g} / \mathrm{mL}$ reduced cell viability from $29.71 \%$ to $1.07 \%$ and $96.12 \%$ to $56.02 \%$, respectively. At higher concentrations, $\mathrm{CHX}$ reduced the viability of cells by 52.36 -fold. The paired $t$-test showed a significant $(p<0.05)$ difference between the mean cell viability of CHK- and MEtreated cells at different concentrations. Kolmogorov-Smirnov test and Shapiro-Wilk test exhibited the normality of the data. Lower D $(<0.2)$, higher $p(>0.9)$, skewness and kurtosis (close to zero) confirmed the normal distribution. One-way ANOVA showed a significant difference $(\mathrm{F}=65.59949 ; p=0.000011)$ between the viability of CHX- and ME-treated HGF cells estimated using MTT assay. Post-hoc Tukey HSD Test, Scheffé, Bonferroni and Holm multiple comparisons also confirmed the statistical significance $(p<0.01)$. Detailed results are shown in Figure 2A-C and Tables 3-7. 

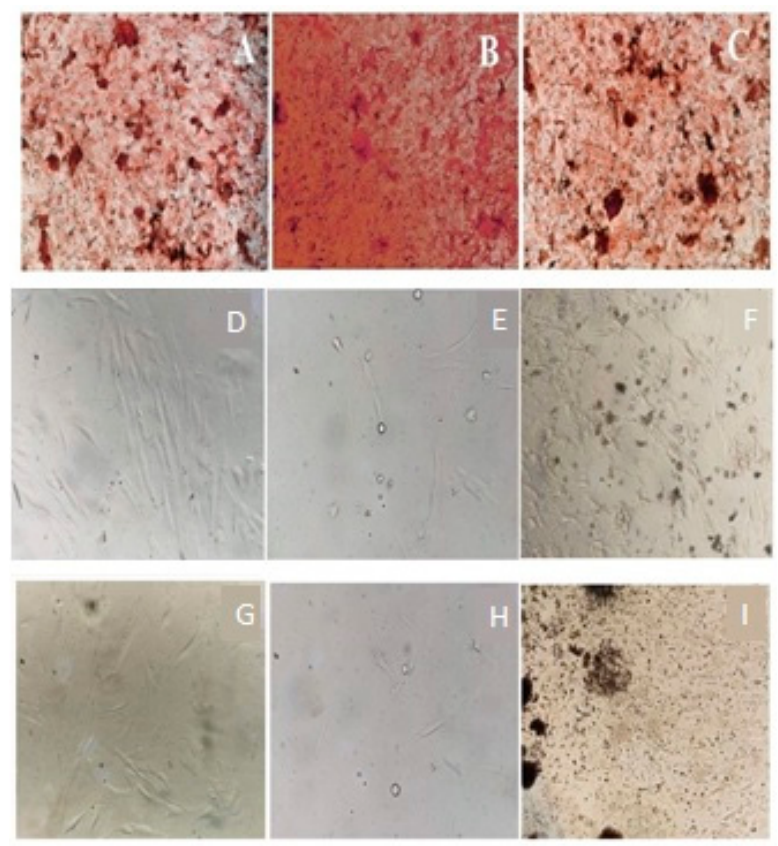

Figure 2. Viability study of $(\mathbf{A}, \mathbf{D}, \mathbf{G})$-negative control; $(\mathbf{B}, \mathbf{E}, \mathbf{H})-\mathrm{CHX}$ treated; and $(\mathbf{C}, \mathbf{F}, \mathbf{I})-\mathrm{ME}$ treated cells using MTT assay (A-C), Neutral red uptake assay (D-F) and Trypan blue assay (G-I), respectively.

Table 3. Cell viability of Primary Gingival Fibroblasts determined using MTT, neutral red, and Trypan blue assay.

\begin{tabular}{|c|c|c|c|c|c|c|}
\hline \multicolumn{7}{|c|}{ Mean Cell Viability \% (Primary Gingival Fibroblast) } \\
\hline \multirow{2}{*}{ Concentration $(\mu \mathrm{g} / \mathrm{mL})$} & \multicolumn{2}{|c|}{ MTT Assay } & \multicolumn{2}{|c|}{ Neutral Red Assay } & \multicolumn{2}{|c|}{ Trypan Blue Assay } \\
\hline & CHX & ME & CHX & ME & CHX & ME \\
\hline 10 & 1.07 & 56.02 & 2.24 & 57.45 & 2.18 & 47.36 \\
\hline 5 & 5.94 & 65.40 & 6.31 & 66.00 & 4.58 & 58.46 \\
\hline 2.5 & 11.11 & 75.87 & 12.63 & 76.54 & 13.01 & 73.08 \\
\hline 1.25 & 17.12 & 84.94 & 18.24 & 87.42 & 18.60 & 80.45 \\
\hline 0.625 & 24.69 & 92.94 & 30.50 & 93.68 & 21.21 & 86.99 \\
\hline 0.3125 & 29.71 & 96.12 & 33.64 & 97.46 & 25.58 & 92.64 \\
\hline Negative Control & \multicolumn{2}{|c|}{100} & \multicolumn{2}{|c|}{100} & \multicolumn{2}{|c|}{100} \\
\hline
\end{tabular}

Table 4. Descriptive ANOVA statistics.

\begin{tabular}{|c|c|c|c|c|c|}
\hline Source & Sum of Squares ss & Degrees of Freedom & Mean Squarems & F Statistic & $p$-Value \\
\hline \multicolumn{6}{|l|}{ MTT assay } \\
\hline Treatment & $12,138.0602$ & 1 & $12,138.0602$ & & \\
\hline Error & 1850.3285 & 10 & 185.0328 & 65.5995 & $* * 0.000011$ \\
\hline Total & $13,988.3887$ & 11 & & & \\
\hline \multicolumn{6}{|c|}{ Neutral red assay } \\
\hline Treatment & $11,718.1250$ & 1 & $11,718.1250$ & & \\
\hline Error & 2074.6763 & 10 & 207.4676 & 56.4817 & $* * 0.00002$ \\
\hline Total & $13,792.8013$ & 11 & & & \\
\hline \multicolumn{6}{|c|}{ Trypan blue assay } \\
\hline Treatment & 1941.7979 & 1 & $10,432.4244$ & & \\
\hline Error & $12,374.2223$ & 10 & 194.1798 & 53.7256 & $* * 0.000025$ \\
\hline Total & 1941.7979 & 11 & & & \\
\hline
\end{tabular}


Table 5. Descriptive statistics of multiple comparisons using a statistical test.

\begin{tabular}{|c|c|c|c|c|c|c|}
\hline \multicolumn{7}{|c|}{ Post-hoc Tukey HSD Test } \\
\hline Assay & $\begin{array}{c}\text { Treatments } \\
\text { pair }\end{array}$ & $\begin{array}{c}\text { Tukey HSD } \\
\text { Q statistic }\end{array}$ & \multicolumn{2}{|c|}{ Tukey HSD $p$-value } & \multicolumn{2}{|c|}{ Tukey HSD inference } \\
\hline MTT & \multirow{3}{*}{$\mathrm{CHX}$ vs. ME } & 11.4542 & \multicolumn{2}{|c|}{0.0010053} & \multicolumn{2}{|c|}{$* * p<0.01$} \\
\hline NR & & 10.6284 & \multicolumn{2}{|c|}{0.0010053} & \multicolumn{2}{|c|}{$* * p<0.01$} \\
\hline $\mathrm{TB}$ & & 10.3659 & \multicolumn{2}{|c|}{0.0010053} & \multicolumn{2}{|c|}{${ }^{* *} p<0.01$} \\
\hline \multicolumn{7}{|c|}{ Scheffé Multiple Comparison } \\
\hline Assay & $\begin{array}{l}\text { Treatments } \\
\text { pair }\end{array}$ & $\begin{array}{c}\text { Scheffé } \\
\text { TT-statistic }\end{array}$ & \multicolumn{2}{|c|}{$\begin{array}{l}\text { Scheffé } \\
p \text {-value }\end{array}$} & \multicolumn{2}{|c|}{$\begin{array}{l}\text { Scheffé } \\
\text { inference }\end{array}$} \\
\hline MTT & & 8.0994 & \multirow{3}{*}{\multicolumn{2}{|c|}{$\begin{array}{l}1.0567 \times 10^{-5} \\
2.0266 \times 10^{-5} \\
2.5123 \times 10^{-5}\end{array}$}} & \multirow{3}{*}{\multicolumn{2}{|c|}{$\begin{array}{l}* * p<0.01 \\
* * p<0.01 \\
* * p<0.01\end{array}$}} \\
\hline NR & CHX vs. ME & 7.5154 & & & & \\
\hline TB & & 7.3298 & & & & \\
\hline \multicolumn{7}{|c|}{ Bonferroni and Holm Multiple Comparisons } \\
\hline Assay & $\begin{array}{c}\text { Treatments } \\
\text { pair }\end{array}$ & $\begin{array}{l}\text { Bonferroni } \\
\text { and Holm } \\
\text { TT-statistic }\end{array}$ & $\begin{array}{l}\text { Bonferroni } \\
p \text {-value }\end{array}$ & $\begin{array}{l}\text { Bonferroni } \\
\text { inference }\end{array}$ & $\begin{array}{c}\text { Holm } \\
p \text {-value }\end{array}$ & $\begin{array}{c}\text { Holm } \\
\text { inference }\end{array}$ \\
\hline MTT & \multirow{3}{*}{$\mathrm{CHX}$ vs. ME } & 8.0994 & $1.0567 \times 10^{-5}$ & $* * p<0.01$ & $1.0567 \times 10^{-5}$ & $* * p<0.01$ \\
\hline NR & & 7.5154 & $2.0266 \times 10^{-5}$ & $* * p<0.01$ & $2.0266 \times 10^{-5}$ & $* * p<0.01$ \\
\hline TB & & 7.3298 & $2.5123 \times 10^{-5}$ & $* * p<0.01$ & $2.5123 \times 10^{-5}$ & $* * p<0.01$ \\
\hline
\end{tabular}

NR: Neutral red; TB: Trypan Blue. ${ }^{* *}$ indicate significant results.

Table 6. Descriptive statistics of ANOVA considering the comparison of viability CHK- and PH-treated HGF cells estimated using a different assay.

\begin{tabular}{|c|c|c|c|c|c|c|}
\hline Description & Source & Sum of Squares ss & Degrees of Freedom & Mean Squarems & F Statistic & $p$-Value \\
\hline \multirow{3}{*}{ ME treated cells } & treatment & 147.9926 & 2 & 73.9963 & & \\
\hline & error & 4013.1105 & 15 & 267.5407 & 0.2766 & $* 0.7622$ \\
\hline & total & 4161.1030 & 17 & & & \\
\hline \multirow{3}{*}{$\begin{array}{l}\text { CHX treated } \\
\text { cells }\end{array}$} & treatment & 30.6475 & 2 & 15.3237 & & \\
\hline & error & 1853.8300 & 15 & 123.5887 & 0.1240 & * 0.8843 \\
\hline & total & 1884.4775 & 17 & & & \\
\hline
\end{tabular}

\subsubsection{Neutral Red Uptake Assay}

$\mathrm{CHX}$ and ME reduced cell viability to a different extent. CHX and PH showed toxicity to approximately $98 \%$ and $42 \%$ of cells, respectively. CHX showed 2.3 -fold higher toxicity to HGF cells compared to ME. The paired $t$-test showed a significant $(p<0.05)$ difference between the mean cell viability of CHX- and ME-treated cells at different concentrations. Lower $\mathrm{D}(<0.2)$, higher $p(>0.9)$, and skewness, kurtosis values confirmed the normal distribution, revealed by the Kolmogorov-Smirnov test. One-way ANOVA showed a significant difference ( $\mathrm{F}=56.4817 ; p=0.00002)$ between the viability of $\mathrm{CHX}$ - and MEtreated HGF cells estimated using the neutral red assay. This is also supported by the post-hoc Tukey HSD test, Scheffé, Bonferroni and Holm multiple comparisons $(p<0.01)$. Cells treated with $\mathrm{CHX}$ and ME were analyzed using the neutral red assay. Detailed results are shown in Figure 2D-F and Tables 3-7.

\subsubsection{Trypan Blue Assay}

At higher concentrations ( $10 \mu \mathrm{g} / \mathrm{mL})$, CHX exhibited toxicity to almost $98 \%$ of HGF cells, whereas ME reduced the proliferation of approximately $53 \%$ of cells. Notably, CHX showed 1.85-fold higher toxicity to HGF cells. Increasing the concentration of $\mathrm{CHX}$ and ME from 0.3125 to $10 \mu \mathrm{g} / \mathrm{mL}$ reduced cell viability from $25.58 \%$ to $2.1 \%$ and $92.64 \%$ to $47.36 \%$, respectively (Table 2$)$. The paired $t$-test showed a significant $(p<0.05)$ difference 
between the mean cell viability of CHX- and ME-treated cells at different concentrations. The Kolmogorov-Smirnov test and Shapiro-Wick test confirmed the normality of the data and hence were analyzed using ANOVA. The value of $\mathrm{F}(53.71799)$ and $p(0.000025)$ confirmed statistical significance within the CHX- and ME-treated cells. The descriptive statistics of ANOVA are shown in Table 3. Post-hoc Tukey HSD test, Scheffé, Bonferroni and Holm multiple comparisons $(p<0.01)$ supported ANOVA results. Cells treated with $\mathrm{CHX}$ and ME were analyzed using trypan blue assay.

Notably, ANOVA showed that the HGF cells' mean viability after performing the MTT, neutral red, and trypan blue assay was not significantly different $(p<0.05)$. This confirms the reliability of results obtained using three assays. Likewise, the viability results of CHK-treated cells were not significantly different. Descriptive statistics of ANOVA, Post-hoc Tukey HSD test, Scheffé, Bonferroni and Holm multiple comparisons have also been made. Detailed results are shown in Figure 2G-I and Tables 3-7.

Table 7. Descriptive statistics demonstrating comparisons of viability results obtained using different assays.

\begin{tabular}{|c|c|c|c|c|c|}
\hline \multicolumn{6}{|c|}{ Post-hoc Tukey HSD Test } \\
\hline Treatment pairs & & $\begin{array}{l}\text { Tukey HSD } \\
\text { Q statistic }\end{array}$ & $\begin{array}{c}\text { Tukey HSD } \\
p \text {-value }\end{array}$ & \multicolumn{2}{|c|}{ Tukey HSD inference } \\
\hline \multicolumn{6}{|l|}{ ME treated cells } \\
\hline A vs. B & & 0.1812 & 0.8999947 & \multicolumn{2}{|c|}{ insignificant } \\
\hline A vs. C & & 0.8067 & 0.8266214 & \multicolumn{2}{|c|}{ insignificant } \\
\hline B vs. C & & 0.9879 & 0.7545422 & \multicolumn{2}{|c|}{ insignificant } \\
\hline \multicolumn{6}{|l|}{$\mathrm{CHX}$ treated cells } \\
\hline A vs. B & & 0.5112 & 0.8999947 & \multicolumn{2}{|c|}{ insignificant } \\
\hline A vs. C & & 0.1639 & 0.8999947 & \multicolumn{2}{|c|}{ insignificant } \\
\hline B vs. C & & 0.6751 & 0.8789620 & \multicolumn{2}{|c|}{ insignificant } \\
\hline \multicolumn{6}{|c|}{ Scheffé Multiple Comparisons } \\
\hline Treatments pair & & Scheffé TT-statistic & Scheffé $p$-value & \multicolumn{2}{|c|}{ Scheffé inference } \\
\hline \multicolumn{6}{|l|}{ ME treated cells } \\
\hline A vs. B & & 0.1281 & 0.9918294 & \multicolumn{2}{|c|}{ insignificant } \\
\hline A vs. C & & 0.5704 & 0.8513402 & \multicolumn{2}{|c|}{ insignificant } \\
\hline B vs. C & & 0.6985 & 0.7865543 & \multicolumn{2}{|c|}{ insignificant } \\
\hline \multicolumn{6}{|l|}{$\mathrm{CHX}$ treated cells } \\
\hline A vs. B & & 0.3615 & 0.9370267 & \multicolumn{2}{|c|}{ insignificant } \\
\hline A vs. C & & 0.1159 & 0.9933079 & \multicolumn{2}{|c|}{ insignificant } \\
\hline B vs. C & & 0.4774 & 0.8930757 & \multicolumn{2}{|c|}{ insignificant } \\
\hline \multicolumn{6}{|c|}{ Bonferroni and Holm Multiple Comparisons } \\
\hline Treatments pair & $\begin{array}{c}\text { Bonferroni and } \\
\text { Holm TT-statistic }\end{array}$ & Bonferroni $p$-value & $\begin{array}{l}\text { Bonferroni } \\
\text { inference }\end{array}$ & Holm $p$-value & Holm inference \\
\hline ME treated cells & & & & & \\
\hline A vs. B & 0.1281 & 2.6992443 & insignificant & 0.8997481 & insignificant \\
\hline A vs. C & 0.5704 & 1.7305385 & insignificant & 1.1536923 & insignificant \\
\hline B vs. C & 0.6985 & 1.4865869 & insignificant & 1.4865869 & insignificant \\
\hline \multicolumn{6}{|l|}{ CHK treated cells } \\
\hline A vs. B & 0.3615 & 2.1683911 & insignificant & 1.4455941 & insignificant \\
\hline A vs. C & 0.1159 & 2.7277837 & insignificant & 0.9092612 & insignificant \\
\hline B vs. C & 0.4774 & 1.9199406 & insignificant & 1.9199406 & insignificant \\
\hline
\end{tabular}

A: MTT assay; B; Neutral red assay; C: Trypan blue assay.

\section{Discussion}

Periodontal diseases are one of the most prevalent chronic conditions globally. Periodontal disease is initiated by the colonization of bacterial pathogens, such as Porphyromonasgingivalis, AggregatibacteractinomycetemcomitansTannerellaforsythus and T. denticola. These microorganisms can stimulate the host defense mechanisms to produce reactive oxygen species that damage the nearby host tissue in addition to destroying the pathogens [35]. 
The lethal action of neutrophil-derived radicals is resisted by the antioxidant enzyme possessed by $p$. gingivalis. The ramifications of this process result in host tissue damage that may subsequently contribute to the destructive process in periodontal disease $[36,37]$. Therefore, efficient medications having potent antioxidant activities with the least or no adverse effects are needed.

Researchers have conjectured that $0.12 \%$ and $0.2 \% \mathrm{CHX}$ with alcohol exhibits significant extrinsic tooth discoloration [38]. Owing to these adverse effects of $\mathrm{CHX}$, various other materials, including nanomaterials, have been studied in dentistry [39,40], and nanoparticle-based antiplaque agents have shown to be efficient in oral biofilm reduction [41]. Presently, an increasingly large variety of phytoconstituents are being studied in experimental models to accomplish the knowledge of their biologic activity in vitro and in vivo [42]. Findings from the present phytochemical analysis revealed that Mimusops elengi Linn (bark) contains active ingredients like alkaloids, sterol, triterpenoids, glycosides, Anthraquinone glycosides, Saponins, Carbohydrates, Flavonoids, Tannins, and proteins. These compounds are known to have anti-bacterial, anti-inflammatory, and antifungal properties [43]. The higher total flavonoid content as estimated in the present study can be associated with the good antioxidant activities reported.

In the present study, cell viability was determined by 3-(4,5-dimethylthiazol-2-yl)-2, 5 -diphenyl tetrazolium bromide (MTT assay) that measures the mitochondrial activity of live cells [44], neutral red uptake assay, where lysosomal uptake of neutral red dye is a highly sensitive indicator of cell viability [45] and Trypan blue assay, which is based on the principle that living cells possess intact cell membranes that exclude this dye, whereas dead cells do not [34]. All three assays showed cell viability. These in vitro tests using cell culture are beneficial due to their simplicity, quickness, low costs, and control of some experimental conditions ( $\mathrm{pH}, \mathrm{CO}_{2}$ concentration, and levels of some molecules) [46,47]. All three assays showed cell viability and based on the results obtained, the null hypothesis is rejected, and the alternate hypothesis stating that there is a significant difference between viability of $\mathrm{ME}$ and CHX treated cells is accepted. The present study results emphasize that low concentrations of the herbal product and CHX produced lesser cytotoxic effects. However, the herbal product significantly retained the cell viability of CHX, revealing its cytoprotective ability (Table 2). This is consistent with the previously published reports [47,48]. This study showed considerable modulation capability (inhibition) depending on the concentration of the product, which is consistent with the findings of [49].

In the present study, the high values of cell viability at lower concentrations may be attributed to the presence of some phytochemical components, such as glucose molecules from tannins and flavonoids. However, the cytotoxicity at higher concentrations may be attributed to the polyphenolic compounds in the herbal product $[38,43]$. There is a dearth of literature on the cytotoxic effects of ME on human gingival fibroblasts. However, the results of a study by [50] revealed a significant decrease in percent mitotic index and root length with time and increasing concentration when cytotoxic effects of ethanolic extract of bark of ME were investigated on meristematic cells of root tips of Allium cepa [50,51] in their study reporting the toxic effect of $\mathrm{CHX}$ beyond $1 \%$ on human gingival fibroblasts at 1-, 5-, and 15-min time exposure. However, Azadirachta indica extract did not adversely affect the fibroblasts even up to $50 \%$ concentration, revealing a less toxic effect than $\mathrm{CHX}$ on the cells [51].

Clinical studies would be beneficial to extrapolate the situation under intact in vivo conditions, where fibroblast interaction with other cellular components including the vasculature is crucial. This is one of the limitations of in vitro studies as in the present study and warrants a need for clinical studies to mimic the in vitro results obtained. Also a larger sample size of studies is needed to validate the cytoprotective potential of the medicinal herb. 


\section{Conclusions}

Within the limitations of the study, it revealed that, the Mimusops elengi Linn bark extract exhibited moderate-to-good antioxidant potential and lowered the cytotoxic effects against HGF cells compared to CHX. This leads us to conclude that it can be used without damage to the gingival tissues. This improved activity could be attributed to its antioxidant potential. The findings of this study highlight the need for further evaluation of the product in clinical studies for its practical and safe application in dental plaque control.

Author Contributions: Conceptualization, S.K.B., M.I.K. and A.M.; methodology, S.K.B., M.I.K., S.J.N. and A.M.; validation, S.K.B., V.J.S., S.J.N., and G.A.S.; formal analysis, A.M. and S.B.P.; investigation, S.K.B.; data curation S.K.B. and A.M.; writing—original draft preparation, S.K.B. and M.I.K.; writingreview and editing, S.L.A.Z., P.M. and G.A.S.; supervision, S.K.B.,V.J.S., A.V. and G.A.S.; project administration, S.K.B., A.V. and M.I.K. All authors have read and agreed to the published version of the manuscript.

Funding: This research was funded by the Deanship of Scientific research, King Khalid University (G.R.P./158/40).

Institutional Review Board Statement: The study was conducted according to the guidelines of the Declaration of Helsinki, and approved by the Institutional Review Board (or Ethics Committee) of KING KHALID UNIVERSITY (Approval No. SRC/ETH/2018-19/116).

Informed Consent Statement: Not applicable.

Data Availability Statement: All data used to support the findings of this study are included in the article.

Conflicts of Interest: The authors declare no conflict of interest.

\section{References}

1. Marsh, P.D. Dental plaque as a biofilm and a microbial community-Implications for health and disease. BMC Oral Health 2006, 6, S1-S14. [CrossRef]

2. Chandki, R.; Banthia, P.; Banthia, R. Biofilms: A microbial home. J. Indian Soc. Periodontol. 2011, 15, 111-114. [PubMed]

3. Figuero, E.; Nóbrega, D.F.; García-Gargallo, M.; Tenuta, L.M.A.; Herrera, D.; Carvalho, J.C. Mechanical and chemical plaque control in the simultaneous management of gingivitis and caries: A systematic review. J. Clin. Periodontol. 2017, 44, S116-S134. [CrossRef]

4. Battino, M.; Bullon, P.; Wilson, M.; Newman, H. Oxidative injury and inflammatory periodontal diseases: The challenge of antioxidants to free radicals and reactive oxygen species. Crit. Rev. Oral Biol. Med. 1999, 10, 458-476. [CrossRef] [PubMed]

5. Chapple, I.L.C. Reactive oxygen species and antioxidants in inflammatory diseases. J. Clin. Periodontol. 1997, 24, 287-296. [CrossRef]

6. Waddington, R.J.; Moseley, R.; Embery, G. Reactive oxygen species: A potential role in the pathogenesis of periodontal diseases. Oral Dis. 2000, 6, 138-151. [CrossRef]

7. Bagchi, S.; Saha, S.; Jagannath, G.; Reddy, V.K.; Sinha, P. Evaluation of efficacy of a commercially available herbal mouthwash on dental plaque and gingivitis: A double-blinded parallel randomized controlled trial. J. Indian Assoc. Public Heal. Dent. 2015, 13, 222-227. [CrossRef]

8. Panpaliya, N.P.; Dahake, P.T.; Kale, Y.J.; Dadpe, M.V.; Kendre, S.B.; Siddiqi, A.G.; Maggavi, U.R. In vitro evaluation of antimicrobial property of silver nanoparticles and chlorhexidine against five different oral pathogenic bacteria. Saudi Dental J. 2019, 31, 76-83. [CrossRef]

9. Mathur, A.; Gopalakrishnan, D.; Mehta, V.; Rizwan, S.; Shetiya, S.; Bagwe, S. Efficacy of green tea-based mouthwashes on dental plaque and gingival inflammation: A systematic review and meta-analysis. Indian J. Dent. Res. 2018, $29,225-232$.

10. Polizzi, E.; Tetè, G.; Bova, F.; Pantaleo, G.; Gastaldi, G.; Capparè, P.; Gherlone, E. Anti-bacterial properties and side effects of chlorhexidinebased mouthwashes. A prospective, randomized clinical study. J. Osseointegration 2020, $12,2-7$.

11. Coelho, A.S.; Laranjo, M.; Gonçalves, A.C.; Paula, A.; Paulo, S.; Abrantes, A.M.; Caramelo, F.; Ferreira, M.M.; Silva, M.J.; Carrilho, E.; et al. Cytotoxic effects of a chlorhexidine mouthwash and of an enzymatic mouthwash on human gingival fibroblasts. Odontology 2020, 108, 260-270. [CrossRef]

12. Bhagwat, D.A.; Kolekar, V.R.; Nadaf, S.J.; Choudhari, P.B.; More, H.N.; Killedar, S.G. Acrylamide grafted neem (Azadirachta indica) gum polymer: Screening and exploration as a drug release retardant for tablet formulation. Carbohydr. Polym. 2020, 229, 115357. [CrossRef]

13. Nadaf, S.; Nnamani, P.; Jadhav, N. Evaluation of Prosopis africana Seed Gum as an Extended Release Polymer for Tablet Formulation. AAPS PharmSciTech 2015, 16, 716-729. [CrossRef] 
14. Parveen, A. Challenges and guidelines for clinical trial of herbal drugs. J. Pharm. Bioallied Sci. 2015, 7, 329-333.

15. Mahesh, G.; Gopal, V. Mimusops elengi Linn. (Sapotaceae); A Promising Dental Care Plant. World J. Pharm. Res. 2018, 7, 269-274.

16. Kumar, H.; Savaliya, M.; Biswas, S.; Nayak, P.G.; Maliyakkal, N.; Setty, M.M.; Gourishetti, K.; Pai, K.S.R. Assessment of the in vitro cytotoxicity and in vivo anti-tumor activity of the alcoholic stem bark extract/fractions of Mimusops elengi Linn. Cytotechnology 2016, 68, 861-877. [CrossRef] [PubMed]

17. Bhavikatti, S.K.; Alqahtani, N.A.; Bhat, K.G.; Aggarwal, V.P.; Karobari, M.I. Evaluation of the anti-inflammatory activity of a mimusops elengi (Linn)-incorporated herbal product: A zymographic analysis. J. Biol. Regul. Homeost. Agents 2020, 34, 157-162.

18. Gami, B.; Pathak, S.; Parabia, M. Ethnobotanical, phytochemical and pharmacological review of Mimusops elengi Linn. Asian Pac. J. Trop. Biomed. 2012, 2, 743-748. [CrossRef]

19. Gami, B. Evaluation of Pharmacognostic and Anti Hemorrhoidal Properties of M. Elengi Lin. Ph.D. Thesis, Veer Narmad South Gujarat University, Gujarat, India, 2007.

20. Singh, K.L.; Srivastava, P.; Kumar, S.; Singh, D.; Singh, V. Mimusops elengi lin (maulsari); A potential medicinal plant. Arch. Biomed. Sci. 2014, 2, 18-29.

21. Choudhary, A.; Smitha, C.N.; Suresh, D.K.; Basu, S.K. Clinival evaluation efficacy of quercus infectoria and Mimusops elengi linn. Herbal preparation in inhibition of gingivitis. Adv. Hum. Biol. 2015, 5, 68-76.

22. Murudkar, A.; Mundhada, S.S.; Tatke, P. Antibacterial activity of Mimusops elengi 1. bark against dental pathogens. Ind. J. Pharm. Educ. Res. 2007, 41, 114-120.

23. Nistane, N.T.; Chauriya, C.B.; Gajbhiy, V.R. A comparative pharmacognostic and antimicrobial evaluation of different parts of Mimusops elengi for dental associated problems. J. Pharmacogn. Phytochem. 2019, 8, 772-779.

24. Zhou, P.; Chrepa, V.; Karoussis, I.; Pikos, M.A.; Kotsakis, G.A. Cytocompatibility Properties of an Herbal Compound Solution Support In Vitro Wound Healing. Front. Physiol. 2021, 12, 653661. [CrossRef] [PubMed]

25. Kotsakis, G.A.; Lan, C.; Barbosa, J.; Lill, K.; Chen, R.; Rudney, J.; Aparicio, C. Antimicrobial agents used in the treatment of peri-implantitis alter the physicochemistry and cytocompatibility of titanium surfaces. J. Periodontol. 2016, 87, 809-819. [CrossRef]

26. Muller, H.D.; Eick, S.; Moritz, A.; Lussi, A.; Gruber, R. Cytotoxicity and antimicrobial activity of oral rinses In Vitro. Biomed. Res. Int. 2017, 40, 19723. [CrossRef] [PubMed]

27. Ramanathan, S.K. Antimicrobial and Antioxidant Activities of Careya arborea Roxb. Stem Bark 2006, 5, 35-41.

28. Manzocco, L.; Anese, M.; Nicoli, M.C. Antioxidant properties of tea extracts as affected by processing. LWT Food Sci. Technol. 1998, 31, 694-698. [CrossRef]

29. Virginia, H.; Sarah, L.E.; Rachel, J.S.; Nathaniel, T.; Joseph, S.; Adam, E.; Cecilia, G. Mitochondrial nitric-oxide synthase: Role in pathophysiology. IUBMB Life 2003, 55, 599-603.

30. Marcocci, I.; Marguire, J.J.; Droy-lefaiz, M.T.; Packer, L. The nitric oxide scavenging properties of Ginkgo biloba extract, Biochem. Biophys. Res. Ommun. 1994, 201, 748-755. [CrossRef] [PubMed]

31. Nadaf, S.J.; Killedar, S.G. Curcumin nanocochleates: Use of design of experiments, solid state characterization, In Vitro apoptosis and cytotoxicity against breast cancer MCF-7 cells. J. Drug Deliv. Sci. Technol. 2018, 47, 337-350. [CrossRef]

32. Van Meerloo, J.; Kaspers, G.J.L.; Cloos, J. Cell sensitivity assays: The MTT assay. Methods Mol. Biol. 2011, 731, $237-245$.

33. Repetto, G.; del Peso, A.; Zurita, J.L. Neutral red uptake assay for the estimation of cell viability/cytotoxicity. Nat. Protoc. 2008, 3, 1125-1131. [CrossRef]

34. Strober, W. Trypan blue exclusion test of cell viability. Curr. Protoc. Immunol. 2001, 21, A.3B.1-A.3B.2.

35. Kakimoto, M.; Inoguchi, T.; Sonta, T.; Yu, H.Y.; Imamura, M.; Etoh, T.; Hashimoto, T.; Nawata, H. Accumulation of 8-hydroxy-2'deoxyguanosine and mitochondrial DNA deletion in kidney of diabetic rats. Diabetes 2002, 51, 1588-1595. [CrossRef]

36. Anusuya, S.; Mlv, P.; Lazarus, F.; Bhavikatti, S.K.; Babrawala, I.S. Estimation of 8-Hydroxy-deoxyguanosine (8-OHdG) in Saliva as a Marker of Oxidative Stress in Patients with Chronic Periodontitis: Preliminary Data. J. Int. Acad Periodontol. 2017, 19, 95-100. [PubMed]

37. Bhavikatti, S.K.; Alqahtani, N.A. Antimicrobial efficacy of a new Mimusops elengi (Linn.) incorporated herbal product on selected oral and periodontal pathogens: An In-Vitro microbiological study. J. Biol. Regul. Homeost. Agents 2020, 34, 635-641. [PubMed]

38. Najafi, M.H.; Taheri, M.; Mokhtari, M.R.; Forouzanfar, A.; Farazi, F.; Mirzaee, M.; Ebrahiminik, Z.; Mehrara, R. Comparative study of $0.2 \%$ and $0.12 \%$ digluconate chlorhexidine mouth rinses on the level of dental staining and gingival indices. Dent. Res. J. 2012, 9, 305-308.

39. Tetè, G.; Capparè, P.; Gherlone, E. New application of osteogenic differentiation from HiPS stem cells for evaluating the osteogenic potential of nanomaterials in dentistry. Int. J. Environ. Res. Public Health 2020, 17, 1947. [CrossRef]

40. Assiry, A.A.; Karobari, M.I.; Bhavikatti, S.K.; Marya, A. Crossover Analysis of the Astringent, Antimicrobial, and Antiinflammatory Effects of Illicium verum/Star Anise in the Oral Cavity. BioMed Res. Int. 2020, 6, 2021.

41. Leung, K.C.F.; Seneviratne, C.J.; Li, X.; Leung, P.C.; Lau, C.B.S.; Wong, C.H.; Pang, K.Y.; Wong, C.W.; Wat, E.; Jin, L. Synergistic anti-bacterial effects of nanoparticles encapsulated with Scutellariabaicalensis and pure chlorhexidine on oral bacterial biofilms. Nanomaterials 2016, 6, 61. [CrossRef]

42. Catão, R.M.; Antunes, R.M.; Arruda, T.A.; Pereira, M.S.; Higino, J.S.; Alves, J.A. Antimicrobial activity "In Vitro" of the ethanol extract Punicagranatum against of Staphylococcus aureus strains. Rev. Bras. Anal. Clin. 2006, 38, 111-114.

43. Mandal, S.; Sircar, B. Anti-bacterial Activity of Mimusops Elengi Leaf, Seed and Bark Extracts Alone and in Combination with Antibiotics against Human Pathogenic Bacteria. Transl. Med. 2016, 6. [CrossRef] 
44. Tolosa, L.; Donato, M.T.; Gómez-Lechón, M.J. General cytotoxicity assessment by means of the MTT assay. Methods Mol. Biol. 2015, 1250, 333-348.

45. De-Deus, G.; Canabarro, A.; Alves, G.; Linhares, A.; Senne, M.I.; Granjeiro, J.M. Optimal Cytocompatibility of a Bioceramic Nanoparticulate Cement in Primary Human Mesenchymal Cells. J. Endod. 2009, 35, 1387-1390. [CrossRef] [PubMed]

46. Schweikl, H.; Schmalz, G. Toxicity parameters for cytotoxicity testing of dental materials in two different mammalian cell lines. Eur. J. Oral Sci. 1996, 104, 292-299. [CrossRef]

47. Nunes, Y.R.F.; Fagundes, M.; Almeida, H.D.S.; Veloso, M.D.D.M. Ecological aspects of Aroeira (MyracrodruonurundeuvaAllemãoAnacardiaceae): Phenology and seed germination. Rev. Arvore 2008, 32, 233-243. [CrossRef]

48. Machado, A.C.; Sartori, P.F.; Damante, C.A.; Dokkedal, A.L.; Oliveira, R.C. Viability of human gingival fibroblast (FGH) treated with ethanolic "aroeira" extract (Myracrodruon urundeuva allemao). Braz. Arch. Biol. Technol. 2016, 59, e16150335. [CrossRef]

49. Queires, L.C.S.; Fauvel-Lafève, F.; Terry, S.; De La Taille, A.; Kouyoumdjian, J.C.; Chopin, D.K.; Vacherot, F.; Rodrigues, L.E.A.; Crépin, M. Polyphenols purified from the Brazilian aroeira plant (Schinus terebinthifolius, Raddi) induce apoptotic and autophagic cell death of DU145 cells. Anticancer Res. 2006, 26, 379-387. [PubMed]

50. Bhujbal, S.S.; Deshmukh, R.P.; Subhashchandra, J.; Bidkar Thatte, V.A.; Awasare, S.S.; Garg, P.P. Evaluation of cytotoxic activity of barks of Mimusops elengi. EurAsian J. Biosci. 2011, 5, 73-79. [CrossRef]

51. Verma, U.P.; Gupta, A.; Yadav, R.K.; Tiwari, R.; Sharma, R.; Balapure, A.K. Cytotoxicity of chlorhexidine and neem extract on cultured human gingival fibroblasts through fluorescence-activated cell sorting analysis: An In-Vitro study. Eur. J. Dent. 2018, 12, 344-349. [CrossRef] 